International Journal of Business Management and Economic Review

Vol. 4, No. 06; 2021

ISSN: 2581-4664

\title{
ASSESSING THE PUBLIC SECTOR EFFICIENCY THROUGH THE PRISM OF THE MILLENNIUM DEVELOPMENT GOALS INDICATORS. THE CASE OF THE REPUBLIC OF MOLDOVA
}

\author{
Silvia Zaharco, PhD \\ Moldova State University, Department of Accounting and Economic Informatics, Republic of Moldova \\ http://doi.org/10.35409/IJBMER.2021.3344
}

\begin{abstract}
This paper examines different ways of assessing the efficiency of the public sector. For the analysis of the public sector efficiency of the Republic of Moldova there were used the indicators of the Millennium Development Goals that reflect economic stabilization and growth, wealth redistribution, allocation of public services, and quality of public administration. For this purpose, the necessary data from the Data Bank of the National Bureau of Statistics were selected. Four groups of indicators were included in the research, starting from poverty reduction, education, gender issues, health and growth rates of Gross Domestic Product. In each group, dependent and independent indicators were determined. And, when estimating the coefficients of behavioral functions, the regression analysis method was applied.
\end{abstract}

Keyword: Public Resources, Poverty, Health, Education, Gender Equality.

\section{INTRODUCTION}

State intervention in economic activity is welcome in order to stimulate economic efficiency and achieve social equity. Usually, when forming an economic policy, the company aims to achieve both greater equality and maximum efficiency.

Efficiency means obtaining useful effects, in the conditions of consuming the financial, material, human resources in a rational and economic way. It must be borne in mind that in the public sector efforts can be well-defined, while the effects, especially the social ones, are difficult to measure and fully predict, as the social framework in which the public sector operates is subject to multiple influences. But these social effects have major implications for the public sector.

Economic efficiency is the fundamental element of resource allocation analyses, regardless of their nature. From the perspective of the public sector economy, efficiency implies the optimal allocation of state resources, in order to achieve a certain level of general well-being. It is well known that public budget resources are not always sufficient to cover public needs. Thus the dilemma arises: what is the optimal level of budget expenditures and how much should the state spend to be considered efficient. However, efficiency is not just about reducing costs. Lower costs may simply mean lower quality of service, which does not contribute to increased efficiency.

Efficiency approaches mainly focus on private sector economic activity. In the public sector, however, the emphasis is more on meeting the needs and less on how to use resources. For a long time, the public sector was considered a non-market one, competition being excluded. This fact has had negative effects on the quality of public goods and services, as well as on the management of public resources. The increase of public needs has led to essential transformations in the way of 


\section{International Journal of Business Management and Economic Review}

Vol. 4, No. 06; 2021

ISSN: 2581-4664

providing the population with public goods and services, as well as in the financing of the institutions responsible for performing this function. One of the first changes in order to ensure the efficiency of the public sector was the ceding of the monopoly by the state over the activities in the public sector (Stoian M. \& Ene N.C., 2003).

For a comprehensive reflection of the reality, it is necessary to assess the efficiency of the public sector both economically and socially. In this context, in order to reveal the degree of efficiency of the public sector, there are appreciated (Șaptefrați T., 2011):

- The degree of accomplishment of the public administration functions, i.e. the comparison of the objectives pursued by the central and local public administrations with the results obtained by them;

- The objectives achieved by the public administration in comparison with the planned objectives, as well as the degree of reflection of the society's real needs;

- The degree of rationality of the adopted decisions, their legitimacy;

- Social utility, economic and socio-political benefit;

- Rationality of public resources use, etc.

The efficiency of the public sector is also reflected in its ability to innovate. For this purpose, the quantifiable benefits that can be obtained on specific sub-domains are determined: public administration, health, education, public policies, etc. The application of innovations in the public sector leads to the increase of the value and quality of public goods and services. Innovation in the public sector involves improving computerization and reducing information asymmetry, optimizing activities through innovative technologies, which can contribute to economic growth (Bloch C. \& Bugge M. M., 2013).

Opening information to the general public and communicating is another criterion for assessing the quality of the public sector. Transparency of public activity and of decisions is vital for any public institution and it contributes decisively to building the image and streamlining its activity. On the other hand, ensuring the transparency of an institution's activity is a response to ensuring that all citizens have the right to information. The citizen who pays taxes and duties has the right to get any information regarding or resulting from the activity of a public institution or authority. Citizens have the right to know such details of public interest as the mission and structure of the institution, development objectives and business plans, promoted policies, their costs, etc. (Tanzi V., 2000).

The evaluation of public sector activity is a complex process influenced by a multiple variety of factors of a political, social and economic nature, so that the evaluation can be carried out in terms of the economic dimension, the social dimension and the political dimension. The delimitation of these meanings is of a theoretical nature, in reality being highlighted the impact of the factors specific to each field on the activity of the public sector.

The size of the public sector is distinguished by the areas in which state intervention is manifested. In general, the state must get involved where the market cannot meet certain requirements and where its intervention is indispensable and effective.

The evaluation of the public sector efficiency has special aspects and can be delimited in the following forms (Howlett M. \& Ramesh M., 2004):

1. Efforts assessment determines the degree of involvement in various fields, i.e. the efforts made at the level of governments to achieve the objectives. The purpose of this evaluation is to establish a database that will be used later in the evaluation of the efficiency or quality of public services.

2. Performance assessment examines the results of the programs, not the efforts made to achieve them. The main objective of performance evaluation is to identify the results of a policy, regardless 


\section{International Journal of Business Management and Economic Review}

Vol. 4, No. 06; 2021

ISSN: 2581-4664

of the formulated objectives.

3. Effectiveness assessment determines the extent to which programs meet their objectives, i.e. the concordance between objectives and performance. Depending on the obtained results, public programs or policies may be modified. This type of evaluation is very useful for those who develop public policies, but it is also the most difficult to undertake due to the existence of a huge volume of information.

4. Efficiency assessment by which the ability to achieve the same results at lower costs is established. Evaluations of efforts and results are the foundation of this type of assessment.

5. Social assessment refers to solving social problems of the society, expressed by such indicators as the level and quality of life of the population, level of education, health care, social welfare, development of science and culture, equalization of income levels of the population, etc.

The quality of the public sector is an important factor in the economic growth. However, the improvement of the public sector cannot take place spontaneously. A well-functioning public administration makes it possible to improve the quality of the public sector. In this context, the European Commission has taken important measures, aimed at increasing the efficiency of the public sector in the countries acceding to the European Union (Antonescu D., 2016):

1. Strengthen the capacity of central and local public administration by improving human resources management, decision-making tools, and coordination within and between different administrative levels, transparency, accountability, integrity.

2. Accelerate the absorption of the EU funds, restructure management and control systems, increase the strategic planning capacity of public administration representatives.

3. Remedy persistent shortcomings in the public procurement sector.

4. Improving the efficiency and quality of the judiciary, combating corruption in all forms and at all levels, effectively enforcing court decisions.

There are several indicators for measuring public sector efficiency. In a certain conception, the efficiency of the public sector is characterized by the results obtained from the use of public resources and it can be measured by means of indicators grouped by the main areas of the public sector (Afonso A. et al., 2006):

1. Administration: corruption level, bureaucracy level, the quality of the judiciary; underground economy.

2. Education: quality of education.

3. Health: infant mortality, life expectancy at birth; health system quality.

4. Distribution: GDP, poverty rate (Gini coefficient).

5. Stability: the rate of inflation change (over the last 10 years), the rate of GDP growth.

6. Economic performance: stability of GDP growth, unemployment rate, level of public debt in GDP.

With the help of these indicators, the authors have assessed the efficiency of the public sector in the Member States of the European Union. The final conclusion is that there are different levels of efficiency depending on public spending. The authors of the study point out that some Member States have significantly increased the efficiency of the public sector by improving economic performance and streamlining public spending. Thus, the increased level of the education process, the effective coverage with quality health services, the high level of competence of public employees, the security of property rights can strongly boost the efficiency of the public sector.

A system for measuring public sector performance has been developed by the World Bank. The 


\section{International Journal of Business Management and Economic Review}

Vol. 4, No. 06; 2021

ISSN: 2581-4664

respective indicators (WGI) allow the appreciation of countries' performances by six dimensions (Public sector achievement in 36 countries, 2015):

1. Corruption control - the extent to which public power is exercised in the private interest, including various forms of corruption, as well as the "capture" of the state by elite groups and private interests.

2. The effectiveness of the government in terms of the quality of public services, the degree of its independence from political pressures, the quality of policy development and implementation.

3. Political stability and absence of violent measures - the risk of destabilizing the government through unconstitutional or violent means.

4. Regulatory quality - the government's ability to formulate and implement public policies aimed at private sector development.

5. The rule of law - the extent to which citizens trust and respect the laws and moral norms of society, as well as the level of crime and violence.

6 . Voice and responsibility - the extent to which the citizens of a country have freedom of choice, freedom of expression, freedom of religion, freedom of association, freedom of assembly, freedom of the press, etc.

However, these indicators are based on subjective data, such as the opinions of experts, entrepreneurs and citizens. It is difficult to formulate quantifiable results in those areas of the public sector. The results of these indicators can only be formulated in general terms: peace and stability, at home and abroad, well and satisfactory, which are difficult to measure in certain indicators.

A system of indicators, which can be used to analyze the efficiency of the public sector, has been developed by the Social and Cultural Planning Office of the Netherlands (SCP). This system includes four groups of indicators (Public sector performance, 2004):

1. Economic stability and growth (unemployment rate, inflation rate, budget deficit, Gross Domestic Product).

2. Redistribution of wealth (poverty rate).

3. Allocation of public services (Education: school dropout rate, rate of people aged 25-34 having higher education studies; Health: life expectancy at birth, mortality in new-borns; Security: criminality).

4. Quality of public administration (bureaucracy; transparency; efficiency; corruption).

These indicators are included in eight Millennium Development Goals (MDGs): reducing extreme poverty and hunger; ensuring access to compulsory general education; promoting gender equality and women empowering; reducing infant mortality; improving maternal health; combating HIV/AIDS, tuberculosis and other diseases; ensuring environmental sustainability; creating global partnership for development (Prohnițchi, V. et al., 2013).

\section{MATERIAL AND METHOD}

The present research focuses on the application of regression analysis to the evaluation of the impact of independent variables, determined as appropriate for each group of indicators examined on the dependent variables. For this purpose, four groups of indicators were selected from the Millennium Development Goals, namely: poverty reduction, education, gender issues, health and growth rates of Gross Domestic Product. In each group, dependent and independent indicators were determined. Subsequently, when estimating the coefficients of the functions of behaviour, the regression 


\section{International Journal of Business Management and Economic Review}

Vol. 4, No. 06; 2021

ISSN: 2581-4664

analysis method was applied.

The necessary data were selected from the Data Bank of the National Bureau of Statistics of the Republic of Moldova.

\section{PUBLIC SECTOR EFFICIENCY IN THE REPUBLIC OF MOLDOVA}

The existence and functioning of the public sector in economic and social life is manifested by the development of the national economy and the increase of social welfare. Through these criteria, the efficiency of the public sector can be appreciated, characterized by the results obtained from the use of public resources and the implementation of public policies aimed at combating poverty, increasing literacy, promoting gender equality and women's empowerment, increasing the quality of health services, etc.

\subsection{Estimation of the function of behaviour regarding poverty and hunger reduction}

In 2000, the Republic of Moldova signed the Millennium Declaration, committing itself to reducing poverty and hunger by reducing the rate of consumption by less than $\$ 4.3$ per day per person, reducing the share of the population below absolute poverty and extreme poverty. These objectives were fully achieved, which led to increased welfare of the population.

The following table presents the result of applying the regression analysis to the calibration of the coefficients for the proposed function of behaviour. The dependence of the variable $\mathrm{Y}$ - the poverty gap index (endogenous estimation variable) of the four independent indicators, nominated below, is examined:

$\mathrm{X} 1$ - absolute poverty rate - exogenous variable;

$\mathrm{X} 2$ - the share of the poorest quintile in the national consumption - exogenous variable;

$\mathrm{X} 3$ - incidence rate of mortality in children aged 0-5 years - exogenous variable;

$\mathrm{X} 4$ - the share of the poorest quintile in the national consumption - exogenous variable.

Table 1. Poverty Gap Index

\begin{tabular}{|l|c|l|l|l|l|}
\hline Years/indicators & $Y$ & $X 1$ & $X 2$ & $X 3$ & $X 4$ \\
\hline 2000 & 0,678 & 0,068 & 0,209 & 0,522 & 0,270 \\
\hline 2001 & 0,546 & 0,065 & 0,198 & 0,380 & 0,280 \\
\hline 2002 & 0,404 & 0,068 & 0,186 & 0,262 & 0,290 \\
\hline 2003 & 0,290 & 0,075 & 0,190 & 0,150 & 0,300 \\
\hline 2004 & 0,265 & 0,072 & 0,171 & 0,147 & 0,310 \\
\hline 2005 & 0,291 & 0,067 & 0,167 & 0,161 & 0,320 \\
\hline 2006 & 0,302 & 0,082 & 0,143 & 0,045 & 0,330 \\
\hline 2007 & 0,258 & 0,081 & 0,128 & 0,028 & 0,340 \\
\hline 2008 & 0,264 & 0,089 & 0,110 & 0,032 & 0,350 \\
\hline 2009 & 0,263 & 0,079 & 0,106 & 0,021 & 0,360 \\
\hline 2010 & 0,219 & 0,081 & 0,095 & 0,014 & 0,370 \\
\hline 2011 & 0,175 & 0,087 & 0,081 & 0,009 & 0,380 \\
\hline 2012 & 0,166 & 0,089 & 0,067 & 0,006 & 0,390 \\
\hline
\end{tabular}


International Journal of Business Management and Economic Review

Vol. 4, No. 06; 2021

ISSN: 2581-4664

\begin{tabular}{|l|l|l|l|l|l|}
\hline \hline 2013 & 0,127 & 0,091 & 0,052 & 0,003 & 0,400 \\
\hline 2014 & 0,114 & 0,097 & 0,039 & 0,001 & 0,410 \\
\hline 2015 & 0,107 & 0,097 & 0,026 & 0,001 & 0,420 \\
\hline
\end{tabular}

Source: Author's personal computations.

After performing the calculations, it was proved that out of these four indicators, three ones are significant, namely: X1, X2, X3.

Table 2. Reducing extreme poverty and hunger

\begin{tabular}{|llll|}
\hline poverty $=1.212 \times \mathrm{X} 1+0.792 \times \mathrm{X} 2+0.757 \times \mathrm{X} 3$ \\
$\sigma$ & $(0.0827)$ & $(0.0766)$ & $(0.0688)$ \\
$t$ & {$[3.6329]$} & {$[2.6756]$} & {$[5.6884]$} \\
$R^{2}=0.991 ; \quad R_{a d j}^{2}=0.9822 ;$ & $F=239.94$ & \\
\hline
\end{tabular}

Source: Author's personal computations.

$t$-- Student's test and $\sigma$ - standard errors are very good, confirming the significance of the estimated coefficients. At the same time, the determination coefficient $\mathrm{R}^{2}$ and the Fisher's $\mathrm{F}$ coefficient prove a good fit of the examined function of behaviour.

The values of the coefficients in addition to the examined indicators suggest that the greatest impact on extreme poverty and hunger comes from the absolute poverty rate, while the poorest quintile in the national consumption and the mortality rate in children aged 0-5 years influence the poverty level almost the same way, by 0.79 and 0.76 units, respectively, when poverty increases by one unit.

The Republic of Moldova has managed to reduce the level of poverty and hunger according to the established targets. However, it is necessary not only to maintain this level, but also to set new, more persevering targets, aimed at improving national living standards and at the same time aligning them with the European ones. At the same time, it is important to address multilaterally the poverty phenomenon, which includes not only the material and financial aspect of the welfare of the population, but also the aspects of social inclusion: social protection, health care, ensuring psychological balance, etc.

\subsection{Estimation of the function of behaviour regarding the literacy rate}

Education plays a key role in ensuring the well-being of the population. The higher is the level of education, the lower is the risk of poverty. The highest rates of poverty are recorded in people/families without education. Thus, one of the primary objectives of the state is to increase the literacy rate among the population.

When evaluating the variable Y - literacy rate, the linear function dependent on the following 


\section{International Journal of Business Management and Economic Review}

Vol. 4, No. 06; 2021

ISSN: 2581-4664

variables was applied:

$\mathrm{X} 1$ - gross enrollment ratio in general mandatory education;

$\mathrm{X} 2$ - degree of employment in preschool institutions;

$\mathrm{X} 4$ - the enrollment ratio in education of children aged 6-7;

$\mathrm{X} 3$ - gross enrollment ratio in preschool education of children aged 3-6 years;

X5 - rate of children enrolled in form I, who had been enrolled in preschool education programs.

Table 3. Literacy rate

\begin{tabular}{|l|l|l|l|l|l|l|}
\hline $\begin{array}{l}\text { Years/ } \\
\text { indicators }\end{array}$ & $Y$ & $X 1$ & $X 2$ & $X 3$ & $X 4$ & $X 5$ \\
\hline 2004 & 0,989 & 0,946 & 0,496 & 0,661 & 0,870 & 0,691 \\
\hline 2005 & 0,995 & 0,944 & 0,519 & 0,707 & 0,890 & 0,756 \\
\hline 2006 & 0,996 & 0,920 & 0,521 & 0,701 & 0,903 & 0,817 \\
\hline 2007 & 0,996 & 0,916 & 0,540 & 0,726 & 0,910 & 0,836 \\
\hline 2008 & 0,996 & 0,909 & 0,557 & 0,744 & 0,911 & 0,878 \\
\hline 2009 & 0,995 & 0,907 & 0,562 & 0,755 & 0,938 & 0,915 \\
\hline 2010 & 0,995 & 0,903 & 0,571 & 0,771 & 0,931 & 0,977 \\
\hline 2011 & 0,995 & 0,901 & 0,589 & 0,796 & 0,928 & 0,975 \\
\hline 2012 & 0,994 & 0,897 & 0,610 & 0,821 & 0,935 & 0,975 \\
\hline 2013 & 0,996 & 0,897 & 0,626 & 0,838 & 0,968 & 0,973 \\
\hline 2014 & 0,994 & 0,893 & 0,638 & 0,839 & 0,959 & 0,977 \\
\hline 2015 & 0,994 & 0,890 & 0,646 & 0,851 & 0,946 & 0,971 \\
\hline
\end{tabular}

Source: Author's personal computations.

As a result of the calculations, the variables $\mathrm{X} 2$ and $\mathrm{X} 3$ proved to be insignificant.

Table 4. Literacy rate

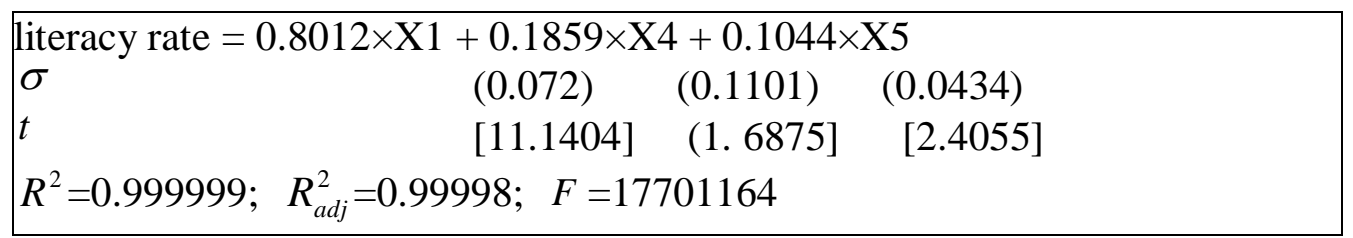

Source: Author's personal computations.

$t$-Student's test and $\sigma$-standard errors are very good, confirming the significance of the estimated coefficients. The coefficient of determination $\mathrm{R}^{2}$ and the Fisher's $\mathrm{F}$ coefficient prove a good fit of the examined function of behavior.

The values of the coefficients in addition to the examined indicators show that the greatest impact on the literacy rate is exerted by the gross enrollment ratio in general mandatory education 0.8 , while the enrollment rate in education of children aged 6-7 regardless of the level in which they 


\section{International Journal of Business Management and Economic Review}

Vol. 4, No. 06; 2021

ISSN: 2581-4664

study is 0.186 and the rate of children enrolled in form I, who had been enrolled in preschool education programs, influences the level of literacy by about 0.104 units and increases the literacy rate by one unit.

The lowest poverty rates are in people with higher education. It should be mentioned that most people with higher education live in urban areas. In rural areas, people with a lower level of education work mainly. This situation is caused by low employment opportunities, low wages, unsatisfactory working conditions for people with higher education in rural areas. In order to recover this situation, it is necessary to implement measures to create and improve jobs in rural areas.

It is important to mention that only quality education with a high degree of accessibility can inevitably lead to poverty reduction. Although, in the context of mass emigration of the rural population, it is unlikely that a significant reduction in education disparities between rural and urban areas will be achieved.

\subsection{Estimating of the function of behaviour regarding the promotion of gender equality and women's empowerment}

In general, in the Republic of Moldova there are no essential inequalities between men and women. These are particularly evident in the integration of women into the labour market and their participation in economic and political life. The most sensitive issues regarding equality between women and men are: the involvement of women in the economic, social and, in particular, the political fields; career advancement; differences in wages; domestic violence. In order to improve the situation, the Government of the Republic of Moldova has carried out various projects to promote gender equality and women's empowerment, it has implemented multiple education programs aimed at facilitating the promotion of women in the labour market, decision-making, entrepreneurship, etc.

In this compartment, the impact of the growth rate of the Gross Domestic Product on the gender indicators was estimated. Starting from the stated objective, we proceeded to calculate an aggregate indicator, namely the weighted average of the values of known gender indicators in gender statistics. The following indicators were examined:

$\mathrm{Y}$ - the growth rate of the Gross Domestic Product;

$\mathrm{X} 1$ - the quota of the mandates held by women in the Parliament;

$\mathrm{X} 2$ - the share of women in decision-making;

$\mathrm{X} 3$ - the share of women employed in the economy (on average by types of economic activities);

$\mathrm{X} 4$ - the share of the average women's earnings from the average men's earnings;

$\mathrm{X} 5$ - weighted average $\mathrm{X} 1 \div \mathrm{X} 4$.

Table 5. Gender equality - women

\begin{tabular}{|l|l|l|l|l|l|l|}
\hline Years/indicators & $\mathrm{Y}$ & $\mathrm{X} 1$ & $\mathrm{X} 2$ & $\mathrm{X} 3$ & $\mathrm{X} 4$ & $\begin{array}{l}\text { X5 } \\
\text { weighted } \\
\text { average }\end{array}$ \\
\hline 2000 & 0,150 & 0,061 & 0,059 & 0,305 & 0,683 & 0,277 \\
\hline 2001 & 0,523 & 0,102 & 0,000 & 0,304 & 0,687 & 0,273 \\
\hline
\end{tabular}




\section{International Journal of Business Management and Economic Review}

Vol. 4, No. 06; 2021

ISSN: 2581-4664

\begin{tabular}{|l|l|l|l|l|l|l|}
\hline \hline 2002 & 0,224 & 0,114 & 0,051 & 0,299 & 0,673 & 0,284 \\
\hline 2003 & 0,160 & 0,125 & 0,050 & 0,295 & 0,672 & 0,286 \\
\hline 2004 & 0,175 & 0,152 & 0,051 & 0,295 & 0,664 & 0,290 \\
\hline 2005 & 0,189 & 0,150 & 0,054 & 0,293 & 0,665 & 0,290 \\
\hline 2006 & 0,194 & 0,134 & 0,021 & 0,286 & 0,626 & 0,314 \\
\hline 2007 & 0,179 & 0,146 & 0,082 & 0,289 & 0,660 & 0,294 \\
\hline 2008 & $-0,041$ & 0,147 & 0,049 & 0,283 & 0,672 & 0,288 \\
\hline 2009 & 0,190 & 0,165 & 0,038 & 0,279 & 0,671 & 0,288 \\
\hline 2010 & 0,146 & 0,138 & 0,034 & 0,279 & 0,680 & 0,283 \\
\hline 2011 & 0,071 & 0,128 & 0,030 & 0,254 & 0,694 & 0,276 \\
\hline 2012 & 0,139 & 0,125 & 0,029 & 0,258 & 0,694 & 0,276 \\
\hline 2013 & 0,115 & 0,127 & 0,029 & 0,254 & 0,695 & 0,276 \\
\hline 2014 & 0,301 & 0,122 & 0,028 & 0,257 & 0,695 & 0,276 \\
\hline 2015 & 0,103 & 0,138 & 0,027 & 0,265 & 0,687 & 0,279 \\
\hline
\end{tabular}

Source: Author's personal computations.

The linear dependence between the growth rate of the Gross Domestic Product and the aggregate gender indicator was further investigated.

Table 6. Gender equality - women

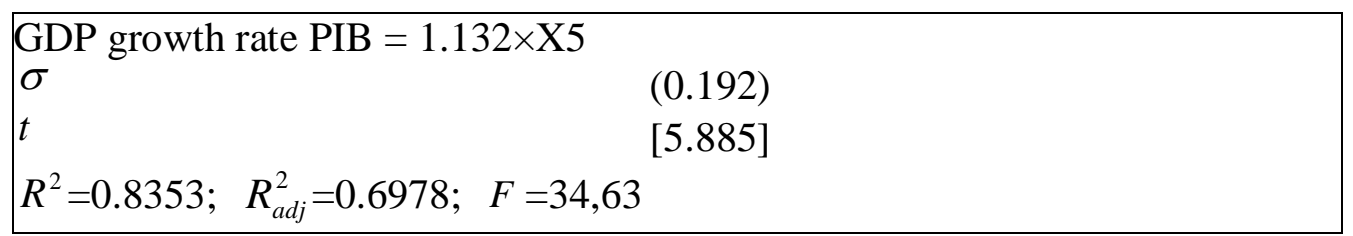

Source: Author's personal computations.

$t$ - Student's test and $\sigma$ - standard error are good enough, confirming the significance of the estimated coefficient. The coefficient of determination $\mathrm{R}^{2}$ and the Fisher's $\mathrm{F}$ coefficient demonstrate a good fit of the examined function of behaviour. The value of the coefficient indicates that the increase of the gross domestic product turnover rate by one percentage contributes to the increase of the aggregate indicator by 1.13 percent.

For comparison, the same estimate was made for men, the following indicators being examined:

$\mathrm{Y}$ - the growth rate of the Gross Domestic Product;

$\mathrm{X} 1$ - the share of mandates held by men in Parliament;

$\mathrm{X} 2$ - the share of men in decision-making;

$\mathrm{X} 3$ - the share of men employed in the economy (on average by types of economic activities);

$\mathrm{X} 4$ - the share of the men's average earnings from the women's average earnings;

$\mathrm{X} 5$ - weighted average $\mathrm{X} 1 \div \mathrm{X} 4$.

Table 7. Gender equality - men 


\section{International Journal of Business Management and Economic Review}

Vol. 4, No. 06; 2021

ISSN: 2581-4664

\begin{tabular}{|l|l|l|l|l|l|l|}
\hline $\begin{array}{l}\text { Years/ } \\
\text { indicators }\end{array}$ & $\mathrm{Y}$ & $\mathrm{X} 1$ & $\mathrm{X} 2$ & $\mathrm{X} 3$ & $\mathrm{X} 4$ & $\begin{array}{l}\text { X5 } \\
\text { weighted } \\
\text { average }\end{array}$ \\
\hline 2000 & 0,150 & 0,339 & 0,518 & 0,360 & 0,312 & 0,383 \\
\hline 2001 & 0,523 & 0,319 & 0,538 & 0,361 & 0,307 & 0,381 \\
\hline 2002 & 0,224 & 0,322 & 0,529 & 0,368 & 0,305 & 0,381 \\
\hline 2003 & 0,160 & 0,318 & 0,530 & 0,372 & 0,302 & 0,381 \\
\hline 2004 & 0,175 & 0,305 & 0,528 & 0,373 & 0,310 & 0,379 \\
\hline 2005 & 0,189 & 0,308 & 0,532 & 0,376 & 0,302 & 0,379 \\
\hline 2006 & 0,194 & 0,330 & 0,445 & 0,382 & 0,350 & 0,377 \\
\hline 2007 & 0,179 & 0,312 & 0,519 & 0,381 & 0,304 & 0,379 \\
\hline 2008 & $-0,041$ & 0,310 & 0,540 & 0,389 & 0,278 & 0,380 \\
\hline 2009 & 0,190 & 0,301 & 0,545 & 0,394 & 0,274 & 0,378 \\
\hline 2010 & 0,146 & 0,313 & 0,543 & 0,392 & 0,271 & 0,380 \\
\hline 2011 & 0,071 & 0,327 & 0,582 & 0,436 & 0,166 & 0,378 \\
\hline 2012 & 0,139 & 0,328 & 0,581 & 0,431 & 0,173 & 0,378 \\
\hline 2013 & 0,115 & 0,328 & 0,585 & 0,438 & 0,159 & 0,378 \\
\hline 2014 & 0,301 & 0,330 & 0,583 & 0,433 & 0,158 & 0,378 \\
\hline 2015 & 0,103 & 0,323 & 0,587 & 0,425 & 0,179 & 0,379 \\
\hline
\end{tabular}

Source: Author's personal computations.

Subsequently, the linear dependence between the growth rate of the Gross Domestic Product and the aggregate gender indicator was investigated. It was found out that $t$-Student's test and $\sigma$ standard error are almost identical to those obtained for women, confirming the good enough significance of the estimated coefficient. The coefficient of determination $\mathrm{R}^{2}$ and the Fisher's $\mathrm{F}$ coefficient demonstrate a good fit of the examined function of behaviour, the values of which differ little from those obtained in women. The value of the coefficient indicates that the increase of the Gross Domestic Product growth rate by one percent contributes to the change of the aggregate indicator by 0.465 percent.

Table 8. Gender equality - men

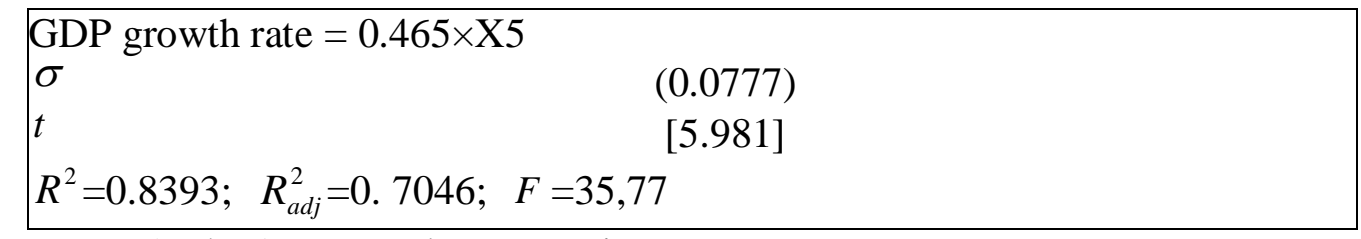

Source: Author's personal computations.

Analyzing the data from Tables 6 and 8, we can conclude that men hold more seats as deputies, they hold more management positions, they are better paid, and their employment in the economy 


\section{International Journal of Business Management and Economic Review}

Vol. 4, No. 06; 2021

ISSN: 2581-4664

exceeds that of women by only about $5 \%$.

Despite all the measures taken by the Government, women continue to be in the minority in leading positions of central and local public authorities in high political forums. Although they have higher education and advanced professional qualifications, women are discriminated against in terms of employment, career advancement, fair pay, etc.

Discrimination against women is motivated by the stereotypes about the role and responsibilities of women and men in both the society and family. The need to take care of children, especially preschool age children, men's absenteeism or insignificant participation in the upbringing and education of children are just a few causes that create impediments in professional development and involvement of women in political, economic and social activities.

\subsection{Estimation of the function of behaviour regarding health}

The objectives of the health system are to continuously improve the health of the population, the financial provision of health services, the use and distribution of health services in an equitable manner, the efficiency of health care. Since 2000 and until now, the health of the population has improved in basic terms, but it is difficult to specify what proportion of these improvements can be specifically attributed to the health system. Access to health services is maintained at a high level, but their quality is in continuous decline.

One of the factors that negatively influences the quality of health services is corruption in the medical system. Although most people have health insurance policies, they are often used only to cover the cost of basic services. In other cases, in order to obtain quality medical services, patients choose to be served in private clinics for a fee or to pay informal payments ("out of pocket").

In this compartment, the impact of the growth rate of the Gross Domestic Product on the aggregate health indicator was estimated. For this purpose, an aggregate indicator was calculated, namely a weighted average of the values of the indicators known from health statistics. The indicators were considered:

$\mathrm{Y}$ - the growth rate of the Gross Domestic Product;

$\mathrm{X} 1$ - infant mortality rate up to 5 years per 1,000 live births;

$\mathrm{X} 2$ - infant mortality rate per 1,000 live births;

$\mathrm{X} 3$ - the share of 2-year-old children vaccinated against measles;

X4 - maternal mortality rate per 100,000 live births;

$\mathrm{X} 5$ - birth rate assisted by qualified medical staff;

X6 - incidence of HIV / AIDS;

X7 - incidence of HIV / AIDS among the population aged 15-24;

$\mathrm{X} 8$ - weighted average $\mathrm{X} 1 \div \mathrm{X} 7$.

Table 9. Health

\begin{tabular}{|l|l|l|l|l|l|l|l|l|l|}
\hline $\begin{array}{l}\text { Years/indi } \\
\text { cators }\end{array}$ & $\mathrm{Y}$ & $\mathrm{X} 1$ & $\mathrm{X} 2$ & $\mathrm{X} 3$ & $\mathrm{X} 4$ & $\mathrm{X} 5$ & $\mathrm{X} 6$ & $\mathrm{X} 7$ & $\begin{array}{l}\text { X8 } \\
\text { weighted } \\
\text { average }\end{array}$ \\
\hline 2000 & 0,150 & 0,233 & 0,183 & 0,891 & 0,271 & 0,99 & 0,040 & 0,104 & 0,176 \\
\hline 2001 & 0,523 & 0,203 & 0,163 & 0,941 & 0,439 & 0,99 & 0,055 & 0,105 & 0,148 \\
\hline 2002 & 0,224 & 0,182 & 0,147 & 0,943 & 0,280 & 0,99 & 0,047 & 0,09 & 0,166 \\
\hline
\end{tabular}




\section{International Journal of Business Management and Economic Review}

Vol. 4, No. 06; 2021

ISSN: 2581-4664

\begin{tabular}{|l|l|l|l|l|l|l|l|l|l|}
\hline \hline 2003 & 0,160 & 0,178 & 0,144 & 0,957 & 0,219 & 0,99 & 0,062 & 0,098 & 0,168 \\
\hline 2004 & 0,175 & 0,153 & 0,122 & 0,963 & 0,235 & 0,99 & 0,084 & 0,134 & 0,162 \\
\hline 2005 & 0,189 & 0,157 & 0,124 & 0,969 & 0,186 & 1,00 & 0,125 & 0,201 & 0,153 \\
\hline 2006 & 0,194 & 0,14 & 0,118 & 0,969 & 0,160 & 1,00 & 0,147 & 0,188 & 0,150 \\
\hline 2007 & 0,179 & 0,14 & 0,113 & 0,947 & 0,158 & 1,00 & 0,174 & 0,212 & 0,148 \\
\hline 2008 & 0,041 & 0,145 & 0,122 & 0,944 & 0,384 & 1,00 & 0,194 & 0,161 & 0,184 \\
\hline 2009 & 0,190 & 0,143 & 0,121 & 0,928 & 0,172 & 0,99 & 0,171 & 0,196 & 0,148 \\
\hline 2010 & 0,146 & 0,136 & 0,117 & 0,903 & 0,445 & 0,99 & 0,171 & 0,21 & 0,162 \\
\hline 2011 & 0,071 & 0,134 & 0,109 & 0,911 & 0,153 & 0,99 & 0,176 & 0,186 & 0,157 \\
\hline 2012 & 0,139 & 0,121 & 0,098 & 0,97 & 0,304 & 1,00 & 0,185 & 0,213 & 0,156 \\
\hline 2013 & 0,115 & 0,12 & 0,094 & 0,968 & 0,158 & 1,00 & 0,179 & 0,191 & 0,153 \\
\hline 2014 & 0,301 & 0,117 & 0,096 & 0,963 & 0,181 & 1,00 & 0,204 & 0,179 & 0,138 \\
\hline 2015 & 0,103 & 0,117 & 0,097 & 0,961 & 0,311 & 1,00 & 0,202 & 0,179 & 0,160 \\
\hline
\end{tabular}

Source: Author's personal computations.

The linear dependence between the growth rate of the Gross Domestic Product and the aggregate health indicator was then investigated.

Table 9. Health

\begin{tabular}{l} 
GDP growth rate $=0.614 \times \mathrm{X} 8$ \\
$\sigma$ \\
$t$ \\
$R^{2}=0.8139 ; \quad R_{a d j}^{2}=0.6624 ; \quad F=29,77$ \\
\hline
\end{tabular}

Source: Author's personal computations.

$t$ - Student's test and $\sigma$ - the standard error confirm the sufficiently good significance of the estimated coefficient. The coefficient of determination $\mathrm{R}^{2}$ and the Fisher's $\mathrm{F}$ coefficient demonstrate a good fit of the examined function of behaviour. The value of the coefficient in addition to the independent variable X8 indicates that the increase in the growth rate of the Gross Domestic Product by one percent contributes to the change of the aggregate indicator by 0.614 percent.

According to the obtained results, each of the established objectives has essential shortcomings, which indicates that the public sector of the Republic of Moldova has not yet reached a high level of efficiency. The most significant discrepancies are observed between the standard of living of the urban and rural population. The rural population is insufficiently provided with water resources, sewerage, education and health services. Some children from low-income families attend kindergartens less. Poorly developed infrastructure, poor quality of social services, lack of viable economic opportunities and other factors make the population emigrate. Even if there is a reduction in the disparity between women and men, women still have lower economic opportunities compared to men.

Consequently, we cannot speak of an increased efficiency of the public sector, being highlighted 


\section{International Journal of Business Management and Economic Review}

Vol. 4, No. 06; 2021

ISSN: 2581-4664

the respective inequalities that generate the division of society, social exclusion, lack of trust, etc. The established Millennium Development Goals expired in 2015, so the need arose to set new goals, thus ensuring the continuity of public sector priorities and commitments. In September 2015, the Declaration of the Summit on Sustainable Development was adopted, through which the Republic of Moldova undertook to reach 106 targets for a better life by 2030 (Sustainable Development Goals, 2017).

The efficiency of the public sector is one of the fundamental priorities of each state, because its inefficiency, along with low management capacity, unfair use of public funds, the existence of inadequate legislation, etc., are the elements that negatively affect the quality of the public sector and economic growth. Achieving effective governance requires the involvement of key factors, such as: openness and transparency, accountability, involvement of citizens and civil society institutions in public affairs. But as long as economic austerity is confused with administrative efficiency, and economic decisions made without political consultation of the population are seen as a model of effective governance, we can just wonder to what extent the state serves its purpose and what kind of content it assumes.

\section{CONCLUSIONS}

In the above mentioned, a quantitative estimation of the Millennium Development Goals indicators was undertaken in terms of reducing extreme poverty and hunger; ensuring access to compulsory general education; promoting gender equality and women's empowering; health. The obtained estimates based on the regression analysis allowed to obtain linear dependencies between the dependent and the independent indicators, proposed for examination. These behavioural relationships offer the possibility to calculate the values of the dependent variables for any year in which the values of the independent variables are known depending on the examined case.

The calculations showed that our country is very good at ensuring access to compulsory general education, but there is a growing interest in secondary, vocational and university education according to the needs of the state for certain specialties that contribute to sustainable economic growth. As to the reduction of extreme poverty and hunger, the state needs to make an increased effort to improve the situation.

In the area of promoting gender equality and women's empowerment, the situation is good enough, but the promotion of women in management positions and in parliament should be more pronounced. Special attention should to be paid to equaling women's earnings to men's earnings. With regard to health, both the calculations and the current situation show that increasing funding in this area, especially in terms of remuneration and ensuring decent working conditions, is imperative.

Finally, we can mention that the key factor that contributes to increasing the efficiency of the public sector is the state's ability to effectively manage public funds, to reduce the risks of maladministration, fraud and corruption. Public sector efficiency requires a higher degree of regulation and good governance reflected in ensuring improved legislation; effective management of public policies; ensuring transparency, integrity and accountability in public administration and the spending of public funds; increasing the efficiency of administrative services, etc. 
International Journal of Business Management and Economic Review

Vol. 4, No. 06; 2021

ISSN: 2581-4664

\section{REFERENCES}

Afonso, A., Schuknecht, L., Tanzi, V., 2006. Public sector efficiency. Evidence for new EU member states and emerging markets. Working paper series no. 581: European Central Bank.

Antonescu, D., 2016. Economic efficiency of public administration in the European Union and Romania. Bucharest: Institute of National Economy.

Bloch, C. and Bugge, M. M., 2013. Public sector innovation from theory to measurement. Journal of Structural Change and Economic Dynamics, 27, pp. 133-145.

Howlett, M. and Ramesh, M., 2004. The study of public policies: cycles and subsystems of policies. Chisinau: Epigraph.

Public sector performance, 2004. The Hague: Social and Cultural Planning Office.

Public sector achievement in 36 countries, 2015. The Hague: The Netherlands Institute for Social Research.

Prohnițchi, V., Bodrug-Lungu, V., Astrahan, A., Ciubotaru, V., 2013. The Third Report on the Millennium Development Goals in the Republic of Moldova. Chisinau: Government of the Republic of Moldova.

Stoian, M. and Ene, N.C., 2003. General and particular aspects in evaluating efficiency in the public sector. ,Public Administration and Management” Journal, 1, pp.30-36.

Şaptefrați, T., 2010. Efficiency of public administration: Assessment criteria and influencing factors. Methodological-scientific journal “Public Administration”, 1(65), pp.23-30.

Tanzi, V., 2000. The role of the State and the quality of the public sector. CEPAL Review, 71, pp. Sustainable Development Objectives, 2017. Annex to letter no. 07/13-682 from 02.08.2017. Ministry of Education, Culture and Research of the Republic of Moldova.

National Bureau of Statistics, 2020. Millennium Development Goals indicators. [online] Availableat: $<$ http://statbank.statistica.md/PxWeb/pxweb/ro/30\%20Statistica\%20sociala/30\%20S tatistica\%20sociala ODM/ODM010100.px/?rxid=4eec3dd5-755a-4e4e-92de-3dc2d391f3a9>.

[Accessed in June 2021]. 